\title{
Jajanan sehat bagi anak-anak berorientasi pangan fungsional berbahan
} dasar ikan laut

Healthy snacks for children oriented to functional made from marine fish

\author{
Sri Handayani ${ }^{1)}$ \\ ${ }^{1}$ Program Studi Teknologi Industri Pertanian, Universitas Tribhuwana Tunggadewi Malang \\ Malang, Jawa Timur \\ Email: handa2308@gmail.com \\ Informasi Artikel: \\ Dikirim: 01/04/2020; ditinjau: 11/06/2020; disetujui: 17/07/2020
}

\begin{abstract}
The purpose of this study was to study the characteristics of caught marine fish at the study site, and to apply the marine fish caught at the study site in the form of healthy snacks, specifically children's snacks. The results of this study indicate that 15 species of fish caught in the Madura strait were 15 types, namely talang-talang (queenfish), tongkol lurik (Euthynnus affinis), tenggiri (Scomberomorus ommerson), mackerel board (Scomberomorus ommerson), alu-alu (Sphyraena barracuda), banyar (Rastreligger kanagurta), white kakap (L. calcarifer), red kakap (Lutjanus spp.), belanak (Valamugil seheli), yellow tail (Caesio cuning), selar como (Alepes djeddaba), babu nyai (Plectorhinchus spp.), black bawal (P. niger), white bawal (P. argenteus), and ketangketang (Epane punctata). The fat content of the marine catch is between $0.43-14.36 \%$ and total fatty acids of 0.02-2.26 g/ $100 \mathrm{~g}$ of fish meat. The results of the second phase of the study, engineering of healthy fish-based snacks carried out in 2 forms, namely modern snacks (13 types) and traditional snacks (11 types).The organoleptic results of the favorite test inform that modern snacks: Bitter ballen and churry burger: very preferred, snacks breaded fish, pastel, scallop, nugget, siomay, fish cakes, burgers, stick fish, and shi kebab: ranged from like to very preferred, fish meatball snacks: ranged from ordinary to like, and ekado: not preferred. While the traditional empek-empek, kroket, lumpia (wet and fried), lemper: ranged from like to very preferred, condro snacks, pastel, arem-arem, onde-onde, otak-otak, and bakwan: ranged from disliked to ordinary.
\end{abstract}

Keywords: functional food, healthy snacks, sea fish

\begin{abstract}
ABSTRAK
Tujuan Penelitian ini adalah untuk mengetahui karakteristik jenis-jenis ikan laut hasil tangkapan di selat Madura, dan mengaplikasikan ikan laut hasil tangkap menjadi bentuk jajanan sehat, khususnya jajanan anak. Hasil penelitian tahap 1, menginformasikan bahwa terdapat 15 jenis ikan laut hasil tangkapan di selat Madura, yaitu ikan talangtalang (queenfish), ikan tongkol lurik (Euthynnus affinis), ikan tenggiri (Scomberomorus ommerson), ikan tenggiri papan (Scomberomorus), ikan alu-alu (Sphyraena barracuda), ikan banyar (Rastreligger kanagurta), ikan kakap putih (L. calcarifer), ikan kakap merah (Lutjanus spp.), ikan belanak (Valamugil seheli), ikan ekor kuning (Caesio cuning), ikan selar como (Alepes djeddaba), ikan babu nyai (Plectorhinchus spp.), ikan bawal hitam ( $P$. niger), ikan bawal putih (P. argenteus), dan ikan ketang-ketang (Epane punctata). Kadar lemak ikan hasil tangkapan laut tersebut berkisar antara 0,43-14,36\%
\end{abstract}


dan total asam lemak antara 0,02 - 2,60 g/100 g daging ikan. Hasil penelitian tahap 2, rekayasa jajanan sehat berbahan dasar ikan laut dilakukan terhadap 2 bentuk, yaitu jajanan modern (13 jenis), dan jajanan tradisional (11 jenis). Hasil organoleptik uji kesukaan menginformasikan bahwa jajanan modern: bitter ballen dan churry burger: sangat disukai, jajanan breaded fish, pastel, scallop, nugget, siomay, fish cake, burger, stick fish, dan shi kebab: berkisar antara disukai hingga sangat disukai, jajanan bakso ikan: berkisar antara biasa hingga disukai, dan ekado: tidak disukai. Sedangkan jajan tradisional empek-empek, kroket, lumpia (basah dan goreng), lemper berkisar antara disukai hingga sangat disukai, jajanan condro, pastel, arem-arem, onde-onde, otak-otak, dan bakwan: berkisar antara tidak disukai hingga biasa.

Kata kunci: ikan laut, jajanan sehat, pangan fungsional

\section{PENDAHULUAN}

Ciri masyarakat modern adalah masyarakat yang sadar akan kebutuhan bahan pangan atau makanan yang dikonsumsinya. Bahan makanan tersebut merupakan pondasi dasar dalam membangun hidup sehat, oleh karena itu tuntutan konsumen terhadap bahan pangan juga kian bergeser. Bahan pangan yang kini mulai banyak diminati konsumen bukan saja yang bernilai gizi baik (primery function), penampilan dan sifat organoleptik yang menarik (secondary function), tetapi juga harus memiliki fungsi fisiologis tertentu bagi tubuh (tertiary function) (Chadwick et al., 2003). Bahan pangan atau makanan yang diprioritaskan pada fungsi tersier disebut pangan fungsional.

Pangan fungsional (functional food) pengertiannya berbeda dengan makanan suplemen, karena dapat dikonsumsi tanpa dosis tertentu. Mengkonsumsi pangan fungsional dalam menu keseharian merupakan keputusan yang sangat baik dan tepat dari segi gizi. Diversifikasi konsumsi pangan fungsional perlu diperkenalkan sedini mungkin sejak masa kanak-kanak, agar setelah dewasa memperoleh manfaat dan khasiat yang optimal. Makanan dari ikan laut mengandung komponen fungsional yang tidak ada dalam organisme darat. Komponen-komponen ini meliputi asam lemak omega 3 (asam lemak n-3 tak jenuh ganda), seperti asam eikosapentanoat (EPA) dan asam dokosaheksanoat (DHA), yang membantu dalam pencegahan penyakit arteriosklerotik dan trombotik. Selain itu makanan berasal dari ikan laut merupakan sumber nutrisi yang baik, seperti protein, asam-asam amino, serat dan mineral (Hosomi et al., 2012; Usydus \& SzlinderRichert, 2012) menambahkan bahwa asamasam amino essential, vitamin D3 dan Selenium yang terdapat pada ikan laut kadarnya lebih dibandingkan makanan lainnya.

DHA memainkan peran penting dalam perkembangan kognitif, performance, fungsi otak dan mata anak-anak yang sedang tumbuh-kembang (Gonzalez \& Baez, 2017) Defisiensi omega-3 (DHA dan EPA) yang terjadi pada anak perempuan berumur 6 tahun dapat menyebabkan gangguan, yakni pandangan mata kabur, dan bermasalah dalam berjalan (Geoffrey, 2007). Asam lemak omega-3 (DHA dan EPA) telah terbukti berpengaruh nyata terhadap retina mata hewan percobaan. Komponen asam lemak omega-3 pada membran sel otak dan retina berpengaruh terhadap fluiditas dan sifat-sifat yang berhubungan dengan aktivitas penglihatan dan reseptor sel syaraf, permeabilitas sel terhadap ion, aktivitas enzim, inisiasi dan transmisi sel syaraf (Duthie \& Barlow, 1992).

Permasalahan saat ini yang sedang dihadapi adalah keengganan anak-anak mengkonsumsi ikan laut, hal ini dikarenakan 1) pemilihan jajanan pada anak didominasi hanya pada cita rasa dan aroma (flavour), 2) adanya duri dalam daging ikan dan bau amis yang tidak disukai anak-anak. Kedua hal ini perlu mendapat perhatian lebih lanjut karena faktor-faktor lain seperti kebiasaan sarapan pagi, uang saku, tingkat pendidikan formal 
dan status pekerjaan ibu, serta pendapatan keluarga tidak memberikan pengaruh yang signifikan dalam pemilihan jajanan anak (Nurbiyati et al., 2014; Syam et al., 2018). Oleh karena itu akan untuk menumbuhkan minat mengkonsumsi jajanan sehat perlu dilakukan rekayasa berbagai macam bentuk dan tampilan jajanan anak sehat yang mempunyai rasa, flavour menarik tanpa meninggalkan arti kandungan gizinya. Tujuan Penelitian ini adalah untuk mengetahui karakteristik jenis-jenis ikan laut hasil tangkapan di selat Madura, dan mengaplikasikan ikan laut hasil tangkap menjadi bentuk jajanan sehat, khususnya jajanan anak.

\section{METODE}

\section{Bahan}

Ikan laut hasil tangkapan di Selat Madura dan Laut Jawa, beras ketan, terigu, pati singkong, telur ayam, dan bumbu rempah.

\section{Alat}

Seperangkat alat analisa untuk total lemak dan asam lemak, lembar uji organoleptik, seperangkat alat proses pembuatan jajanan sehat.

\section{Desain percobaan}

Metode penelitian ini merupakan penggabungan antara metode kualitatif dan kuantitatif, yaitu mengkarakterisasi hasil tangkapan ikan laut dengan uji rekayasa produk jajanan sehat pada anak-anak sebagai responden.

\section{Responden}

Penentuan populasi atau sampel dilakukan dengan purposive sampling, yaitu anak-anak yang duduk di bangku Sekolah Dasar di lingkungan perkotaan Kabupaten Sidoarjo. Jumlah Sekolah Dasar atau lokasi yang terpilih sebanyak 5, dan masing-masing dipilih 30 siswa sebagai responden.

\section{Pengumpulan data}

Teknik pengumpulan data yang digunakan meliputi wawancara kepada pihak yang terlibat dalam penelitian, observasi lapangan jenis-jenis ikan laut hasil tangkapan, survey jajanan di sekolah sebagai langkah awal untuk mengidentifikasi jajanan yang berbahan dasar ikan laut pada keseharian anak-anak SD. Setelah diperoleh gambaran jelas, maka dilakukan rekayasa pangan fungsional berbahan dasar ikan laut dalam bentuk jajanan sehat.

\section{Tahapan penelitian}

Penelitian ini terdiri atas 2 tahapan, tahapan I adalah karakterisasi jenis ikan laut hasil tangkapan di selat Madura yang dapat dimanfaatkan sebagai pangan fungsional. Sedangkan tahapan II adalah tahap rekayasa bentuk jajanan sehat anak berpotensi pangan fungsional berbahan dasar ikan laut.

\section{HASIL DAN PEMBAHASAN}

\section{Karakterisasi hasil tangkapan ikan laut di lokasi penelitian}

Banyak sebutan yang sering diberikan untuk laut dan segala potensinya, di antaranya sebagai the complete protein karena laut sebagai penyedia bahan makanan sumber protein, di antaranya ikan, udang, rajungan, kerang, tiram, cumi-cumi, dan sebagainya. Bahan makanan tersebut selain prospektif (bernilai jual tinggi), juga memiliki nilai protein dan asam lemak dalam minyak ikan yang sempurna (Dahuri, 2002).

Dalam penelitian ini ikan laut hasil tangkapan yang mempunyai nilai ekonomis meliputi 15 jenis ikan, yaitu ikan talangtalang (Queenfish), ikan tongkol lurik (E. affinis), ikan tenggiri (Scomberomorus mmerson), tenggiri papan (scomberomorus spp.), ikan alu-alu ( $S$. barracuda), ikan banyar (Rastreligger kanagurta), ikan kakap putih (L. calcarifer), ikan kakap merah (Lutjanus spp), ikan belanak (Valamugil seheli), ikan ekor kuning (Caesio cuning), ikan selar como (Alepes djeddaba), ikan babu nyai (Plectorhinchus spp), ikan bawal hitam ( $P$. niger), ikan bawal putih ( $P$. argenteus), dan ikan ketang-ketang (Epane punctata).

Morfologi jenis-jenis ikan laut hasil tangkapan di lokasi penelitian adalah sebagai berikut: 
1. Ikan talang-talang atau ikan daun bambu, atau queenfish

Ikan talang-talang disebut juga ikan daun bambu atau queenfish. Bentuk badannya pipih dan memanjang, moncong tumpul, pada kepala terdapat suatu lekukan di atas mata, warna badan bagian atas hijau perunggu, bagian bawah keemasankeperakan, terdapat 5-8 bintik-bintik bulat pada sisi-sisi badan.

2. Tongkol como atau tongkol lurik (Euthynnus affinis)

Terdapat tiga jenis ikan tongkol yang sering dijumpai,yaitu sebagai berikut: 1) ikan tongkol krai, 2) ikan tongkol lurik, 3) ikan tongkol abu-abu.

\section{Ikan tenggiri (Scomberomorus ommerson)}

Ikan tenggiri (S. commerson), mempunyai ciri khas yaitu pada sirip punggungnya yang berjari-jari, sirip keras berwarna biru kehitam-hitaman.

4. Ikan tengiri papan (Scomberomorus guttatus)

Tenggiri papan (S. guttatus), mempunyai ciri-ciri: pada sirip punggung yang berjari-jari keras berwarna gelap secara merata, pada bagian sisi tubuhnya terdapat beberapa titik hitam yang besarnya sama dengan pupil matanya. Lebar badannya hampir sama dengan panjang kepalanya.

\section{Ikan alu-alu (Sphyraena barracuda)}

Ikan alu-alu disebut juga dengan nama kucul, kocol, barangasa, kalasowa, atau buton muna. Warna punggung abu-abu kebiruan, warna badan bagian bawah keperak-perakan, terdapat 18-23 ban-ban yang membentuk sudut melintang badan melalui garis rusuk. Kedua sirip punggungnya biru kehitaman dan pada ujung sirip dubur warnanya agak gelap. Warna sirip-siripnya kuning keabuabuan; pada bagian ujung dari sirip punggung kedua, dubur, dan ekor berwarna putih. Badannya memanjang, agak gilig, sedikit gepeng. Mulutnya lebar dengan rahang bawah agak menonjol ke depan.
6. Ikan banyar (Rastreligger kanagurta)

Warna ikan banyar biru kehitaman atau kehijauan, warna badan bagian bawah keperakan sedikit keemasan. Warna sirip punggungnya kekuningan dengan bagian tepinya gelap, sirip ekor dan dada kekuningan, sedangkan sirip dubur dan sirip-sirip lain keabu-abuan.

\section{Ikan kakap (Lates calcarifer)}

Ikan kakap memiliki ciri-ciri: bentuk badan pipih, bulat panjang, kepalanya tipis melebar, moncongnya meruncing dan ditutupi sisik. Mulut ikan kakap termasuk lebar, rahang bawahnya lebih panjang dari pada rahang atasnya, tepi belakang dari tutup insang depan bergerigi, sedang pada tepi bawahnya terdapat beberapa duri condong ke bawah. Sirip dada ekor dan dubur membulat sedangkan sirip punggung berjari-jari keras dan jari-jari lemah berhubungan di dasarnya atau bersatu. Tubuh bagian atas berwarna cokelat keemasan, bagian bawah keperakan dan panjangnya dapat mencapai $170 \mathrm{~cm}$.

\section{Ikan kakap merah (Lutjanus spp)}

Ikan kakap merah sering juga disebut sebagai ikan bambangan, darongan, kalelet, posepa, bacan atau moros. Bentuk badannya memanjang, melebar dan gepeng, profil kepala lurus atau sedikit cekung. Ikan kakap merah panjangnya bisa mencapai $90 \mathrm{~cm}$, umumnya panjangnya sekitar $35-50 \mathrm{~cm}$.

\section{Ikan belanak (Valamugil seheli):}

Ikan belanak disebut juga ikan kada. Belanak laut (Valamugil seheli), biasa hidup di perairan pantai dan estuarin. Ciri-cirinya: warna badannya sebelah atas cokelat kehijau-hijauan, dan sebelah bawah keperak-perakan.

\section{Ikan ekor kuning (Caesio cuning)}

Ikan ekor kuning disebut juga ikan lolosi biru, kunir pito, wakung, bek-bek, delah, dan rapo-rapo. Badannya memanjang, melebar, gepeng. Mulutnya kecil. Panjang badannya bisa mencapai $60 \mathrm{~cm}$, tetapi umumnya $30-40 \mathrm{~cm}$. Warna badannya biru keabu-abuan atau biru 
gelap, warna badan bagian bawah lebih pucat, terdapat pita kuning melebar pada punggung dari awal sirip punggung menutup cagak sirip ekor dan terdapat garis biru di sekitar mata.

\section{Ikan selar como (Alepes djeddaba)}

Ikan selar como memiliki profil tubuh bagian punggung dan bagian perut cembung, tinggi melebar dan sedikit membulat. Tubuh ikan bagian atas berwarnanya hijau atau biru dan bagian bawah berwarna putih keperakan. Siripnya berwarna kuning pucat, terutama pada sirip ekor. Bagian dada bersisik dan terdapat noktah hitam di pinggir atas tutup insang.

\section{Ikan babu nyai (Plectorhinchus spp)}

Ikan babu nyai biasa juga di sebut ikan gaji. Bentuk badannya lonjong pipih, pada bagian kepalanya ditutupi sisik hingga sampai depan matanya, mulutnya kecil dan bibirnya tebal. Pada ikan babu nyai muda, terdapat pita hitam memanjang sedangkan pada ikan yang sudah dewasa terdapat noktah-noktah hitam.

\section{Ikan bawal hitam (Parastromateus niger)}

Bawal hitam sering juga disebut sebagai ikan dorang, dibas, kapet dan ikan pedapeda lotong. Ciri-ciri ikan bawal hitam adalah badannya melebar, gepeng, mulutnya kecil, terdapat sisik duri pada bagian ekornya. Panjang badannya mencapai $30 \mathrm{~cm}$. Warna badan bagian atas cokelat, sedang badan bagian bawah putih keperakan.

\section{Ikan bawal putih (Pampus argenteus)}

Bawal putih sering juga disebut sebagai ikan loang atau ikan darah. Warna tubuh ikan bawal putih adalah abu-abu pada bagian atas dan semakin ke bawah berwarna putih, bentuk tubuhnya pipih, tulang rahang bawahnya berakhir pada mata bagian bawah. Seluruh sirip ikan bawal putih berwarna kuning pucat, pada sirip punggung dan sirip perut bagian tepinya berwarna kehitaman.

\section{Ikan ketang-ketang (Drepane punctata)}

Ikan ketang-ketang disebut juga dengan ikan tapak, tebel, bongkah, tapi-tapi, papatik dan taweh. Ikan ini badannya sangat lebar dan gepeng. Kepala ikan ketang-ketang pendek dengan ukuran mulut relatif kecil. Sirip dada berukuran relatif sangat panjang, berbentuk sabit, dan ujungnya mencapai hingga sirip ekor. Badannya berwarna putih perak , sedikit keunguan atau kekuningan. Warna ungu berangsur-angsur memudar ke arah belakang.

\section{Kandungan gizi ikan laut sebagai bahan dasar pangan fungsional pada jajanan sehat anak}

Jajanan merupakan makanan ringan yang sangat banyak variasinya. Seiring dengan kemajuan informasi semakin banyak juga variasi ragam jajanan baik yang bernuansa tradisional maupun nasional bahkan internasional.

Sehat tidaknya jajanan dipengaruhi oleh kandungan senyawa penyusunnya dan bagaimana cara mengolah jajanan tersebut. Proses pengolahan makanan yang tidak tepat memungkinkan terjadinya penurunan nilai gizi bahan makanannya. Penurunan nilai gizi ini dikarenakan gizi bahan makanan peka terhadap perubahan $\mathrm{pH}$, oksigen, cahaya, dan panas, atau kombinasi di antaranya. Sebagai contoh asam lemak omega-3 stabil dalam lingkungan lembab, dan akan mudah rusak jika dipanaskan pada lingkungan beroksigen, serta akan menjadi rusak sama sekali jika mengalami oksidasi atau dehidrogenasi.

Terdapat tiga indikator pemilihan makanan jajanan yaitu 1) pemilihan terkait personal, 2) pemilihan terkait sosial ekonomi dan 3) pemilihan terkait ketersediaan makanan jajanan yang ada (Iklima, 2017). Ketersediaan makanan memegang peranan yang cukup penting, misalnya berkontribusi dalam penyediaan energi dan asupan zat gizi bagi anak-anak usia sekolah. Jajanan anak sekolah yang tidak sehat, sangat berpotensi menyebabkan terjadinya keracunan, gangguan pencernaan anak dan jika berlangsung lama dapat menyebabkan status 
gizi yang buruk (Dyna et al., 2018; Nurbiyati et al., 2014).

Jajanan berbahan ikan laut, bila tepat penanganan dan cara pengolahannya bisa berfungsi sebagai pelengkap asupan gizi makanan yang kita makan. Dipilihnya ikan laut sebagai bahan jajanan karena ikan mengandung protein dan nilai gizi tinggi , tersusun oleh sejumlah asam amino yang dibutuhkan manusia. Protein ikan sangat mudah dicerna dan diserap tubuh, karena daging ikan memiliki serat-serat yang lebih pendek dibandingkan dengan serat protein hewani lainnya. Demikian pula lemak/ minyak ikan juga sangat bermanfaat bagi kesehatan dan kecerdasan. Permasalahan terhadap kelebihan kolesterol sehingga menjalani diet lemak, dapat ditanggulangi dengan mengkonsumsi lebih banyak ikan laut kaya asam lemak omega-3 untuk memenuhi kebutuhan asam lemak esensialnya. Mengkonsumsi ikan sebanyak rata-rata 30 gram perhari dapat mereduksi risiko kematian akibat penyakit jantung hingga 50 persen. Asam lemak omega-3 juga mempunyai peran penting dalam proses pembentukan sel-sel saraf, termasuk sel otak pada anak-anak untuk meningkatkan kecerdasan, terutama pada saat proses tumbuh kembang (Diana, 2013).

Minyak ikan didominasi oleh asam linolenat, asam eikosapentanoat (EPA) dan asam dokosaheksanoat (DHA). Asam lemak tak jenuh pada minyak ikan tersebut merupakan asam lemak omega-3 yang berperan mencegah penyakit jantung dan penyakit degenaratif lainnya serta dapat mengatasi beban penderita penyakit sesak bawaan (asma), rematik, penyakit kulit, menyempurnakan pertumbuhan sel otak pada balita.

Sumber utama asam lemak omega 3 bahan makanan adalah ikan laut khususnya yang sumber makanannya berasal dari mikroalga atau fitoplankton. Hasil penelitian terkait fitoplankton Chaetoceros $s p$. mengandung omega-3 (Herawati, 2019) lebih tinggi dibandingkan Tetraselmis $s p$, Nitzchia, Chlorella dan Spirulina. Golongan ikan dengan kandungan omega-3 relatif tinggi di antaranya adalah jenis ikan tuna, ikan tongkol, ikan Tenggiri, ikan layang, ikan kembung, ikan bawal, ikan sarden atau makerel, ikan herring dan ikan haibut. Asam lemak omega-3 adalah asam lemak yang memiliki posisi ikatan rangkap pertama pada atom karbon nomor tiga dari gugus metil.

Spingomielin dibentuk oleh EPA dan

DHA. Spingomielin berperan untuk membentuk membran sel otak dan mielin sel saraf. Jumlah EPA dan DHA bila terdapat pada otak cukup, maka sinyal yang disampaikan dari otak akan diteruskan ke akson, dan myelin akan mempercepat jalannya sinyal yang disampaikan oleh otak. Pesan yang disampaikan oleh otak tersebut akan diteruskan oleh neurotransmitter sesuai dengan perintah otak sehingga perkembangan gerak motorik tubuh yang dihasilkan menjadi cepat dan berkembang dengan baik (Diana, 2013).

Berdasarkan hasil uji laboratorium (tabel 1), menginformasikan bahwa kandungan total lemak tidak berkolerasi dengan kandungan asam lemak daging ikan laut. Ikan laut yang hidupnya selalu bergerombol dan habitatnya di perairan dalam (ikan tengiri, tuna, layang, kembung dan tongkol ) kandungan asam lemaknya mempunyai kecenderungan lebih tinggi dibanding jenis ikan karang dan ikan pelagis lainnya (Bawal hitam, ekor kuning , kakap merah, babu nyai, selar dan talang-talang ).

Tabel 1. Kandungan total lemak dan asam lemak ikan laut di lokasi penelitian

\begin{tabular}{lcc}
\hline \multicolumn{1}{c}{ Nama Ikan } & $\begin{array}{c}\sum \text { Lemak } \\
(\mathbf{\%})\end{array}$ & $\begin{array}{c}\text { Asam } \\
\text { lemak } \\
(\mathbf{g} / \mathbf{1 0 0 g})\end{array}$ \\
\hline Tuna & 1,33 & 2,1 \\
Tongkol & 6,78 & 1,5 \\
Tenggiri & 10,23 & 2,60 \\
Layang & 1,35 & 2,10 \\
Kembung/banyar & 2,42 & 2,20 \\
Bawal hitam & 14,00 & 0,60 \\
Ekor kuning & 1,37 & 0,29 \\
Kakap merah & 0,55 & 0,13 \\
Babu nyai & 0,52 & 0,21 \\
Selar & 14,36 & 0,68 \\
Talang-talang & 0,43 & 0,02 \\
\hline
\end{tabular}

Sumber: Laboratorium PMKP UB (2019) 


\section{Rekayasa jajanan sehat berbahan dasar ikan laut}

Ikan laut merupakan bahan makanan yang memiliki aroma khas, bila mengalami sedikit kemunduran mutu berubah menjadi amis. Aroma amis dan duri ikan sering menyebabkan sebagian orang tidak menyukai jajanan berbahan baku ikan laut. Pada penelitian ini, bau amis ikan dicegah atau dikurangi dengan cara pada saat pencucian ikan air yang digunakan harus mengalir, setelah bersih dipotong bagian kepala dan dikeluarkan usus serta bagian pencernaan lainnya. Ikan selanjutnya direndam dengan menambahkan air jeruk nipis. Dengan cara pencucian seperti ini, akan diperoleh daging ikan yang segar, tidak berbau amis dan kesat. Bau amis (off odor) ikan dikarenakan adanya senyawa Trimetilamina $N$-oksida (TMAO) sebagai hasil oksidasi senyawa Trimetilamina (TMA) oleh bakteri. Terbentuknya senyawa TMAO $\left(\mathrm{CH}_{3}\right)_{3} \mathrm{NO}$ dapat dimulai dari proses penangkapan ikan, proses pengolahan hingga penyimpanan ikan.
Adanya duri pada ikan dihilangkan dengan cara menarik bagian ekor ikan dan pegang kepala ikan sampai patah tulangnya. Hal ini dilakukan agar duri ikan bisa mengelompok ke bagian tengah badan ikan, dan memudahkan untuk memotong dan mengambil durinya.

Pada penelitian ini, rekayasa jajanan sehat berorientasi pangan fungsional dilakukan pada jajanan tradisional maupun non-tradisional (modern), dengan penyimpanan suhu kamar $\left(25-27^{\circ} \mathrm{C}\right)$, suhu dingin $\left(4^{\circ} \mathrm{C}\right)$ dan suhu beku (di bawah $\left.-4^{\circ} \mathrm{C}\right)$.

Kelayakan rekayasa jajanan sehat dalam penelitian ini diuji secara organoleptik kepada 25 panelis untuk diketahui tingkat kesukaannya terhadap rasa, aroma, tekstur, dan warnanya. Jajanan yang mendapatkan rekomendasi layak produksi yaitu skor ratarata 4 hingga 5 atau kriteria disukai hingga sangat disukai, selanjutnya diuji lebih lanjut ke konsumen (dalam hal ini anak-anak sekolah ). Hasil organoleptik disajikan pada Tabel 2.

Tabel 2. Uji organoleptik rekayasa jajanan sehat berorientasi pangan fungsional berbahan dasar ikan laut jenis jajanan tradisional

\begin{tabular}{llccccc}
\hline No & \multicolumn{1}{c}{ Pangan fungsional } & $\begin{array}{c}\text { Rerata } \\
\text { nilai } \\
\text { rasa }\end{array}$ & $\begin{array}{c}\text { Rerata } \\
\text { nilai } \\
\text { warna }\end{array}$ & $\begin{array}{c}\text { Rerata } \\
\text { nilai } \\
\text { tekstur }\end{array}$ & $\begin{array}{c}\text { Rerata } \\
\text { nilai } \\
\text { aroma }\end{array}$ & $\begin{array}{c}\text { Rerata tes } \\
\text { organo- } \\
\text { leptik }\end{array}$ \\
\hline 1 & Kroket (ikan ketang-ketang) & 3,52 & 3,16 & 3,42 & 3,12 & 3,305 \\
2 & Condro (ikan bawal) & 2,68 & 2,16 & 3,46 & 2,56 & 2,715 \\
3 & Lumpia basah (ikan banyar) & 3,52 & 3,38 & 2,68 & 2,42 & 3,000 \\
4 & Lumpia goreng (ikan selar) & 4,02 & 4,34 & 3,42 & 3,56 & 3,835 \\
5 & Pastel (ikan ketang-ketang) & 2,48 & 2,52 & 2,33 & 2,09 & 2,355 \\
6 & Lemper (ikan kakap merah) & 4,68 & 3,60 & 4,32 & 3,22 & 3,955 \\
7 & Arem-arem (ikan selar) & 2,56 & 2,43 & 2,22 & 2,46 & 2,418 \\
8 & Onde-onde (ikan ekor kuning ) & 2,63 & 2,63 & 3,78 & 2,58 & 2,905 \\
9 & Otak-otak (ikantongkol) & 2,42 & 2,47 & 2,33 & 2,58 & 2,450 \\
10 & Bakwan (ikan layang) & 2,21 & 2,21 & 2,46 & 2,42 & 2,325 \\
11 & Empek-empek (ikan tengiri) & 4,24 & 4,24 & 4,68 & 4,02 & 4,295 \\
\hline
\end{tabular}

Keterangan:

Nilai 1: sangat tidak suka

Nilai 2: tidak suka

Nilai 3: biasa/netral

Nilai 4: suka

Nilai 5: sangat suka 
Tabel 3. Uji Organoleptik rekayasa jajanan sehat berorientasi pangan fungsional berbahan dasar ikan laut jenis jajanan non-tradisional (modern)

\begin{tabular}{clccccc}
\hline No & \multicolumn{1}{c}{ Pangan Fungsional } & $\begin{array}{c}\text { Rerata } \\
\text { Nilai } \\
\text { Rasa }\end{array}$ & $\begin{array}{c}\text { Rerata } \\
\text { Nilai } \\
\text { Warna }\end{array}$ & $\begin{array}{c}\text { Rerata } \\
\text { Nilai } \\
\text { Tekstur }\end{array}$ & $\begin{array}{c}\text { Rerata } \\
\text { Nilai } \\
\text { Aroma }\end{array}$ & $\begin{array}{c}\text { Rerata } \\
\text { Tes } \\
\text { Organo } \\
\text {-leptik }\end{array}$ \\
\hline 1 & Ekado (ikan tuna) & 2,48 & 2,62 & 2,31 & 2,02 & 2,36 \\
2 & Fish cake (ikan babu nyai ) & 4,82 & 4,74 & 4,82 & 4,23 & 4,65 \\
3 & Burger (ikan tuna) & 5,00 & 5,00 & 4,42 & 4,88 & 4,83 \\
4 & Nugget (ikan kakap ) & 5,00 & 5,00 & 5,00 & 5,00 & 5,00 \\
5 & Shi kebab (ikan tuna) & 4,24 & 4,06 & 4,06 & 4,24 & 4,15 \\
6 & Chury burger (ikan tengiri) & 5,00 & 5,00 & 5,00 & 5,00 & 5,00 \\
7 & Breaded fish (ikan tuna) & 5,00 & 5,00 & 4,98 & 4,96 & 4,99 \\
8 & Stick fish (ikan bawal) & 4,72 & 4,72 & 4,02 & 4,52 & 4,50 \\
9 & Scallop (ikan belanak) & 5,00 & 4,76 & 4,68 & 4,88 & 4,83 \\
10 & Bitter balen (ikan selar) & 5,00 & 5,00 & 5,00 & 5,00 & 5,00 \\
11 & Pastel beku (ikan ekor kuning ) & 5,00 & 4,86 & 4,98 & 4,98 & 4,96 \\
12 & Bakso (ikan layang) & 4,2 & 3,48 & 3,78 & 3,57 & 3,76 \\
13 & Siomay (ikan kakap ) & 4,88 & 4,86 & 4,66 & 4,32 & 4,68 \\
\hline
\end{tabular}

Keterangan:

Nilai 1: sangat tidak suka

Nilai 2: tidak suka

Nilai 3: biasa/netral

Nilai 4: suka

Nilai 5: sangat suka

Hasil analisa bahan baku (tabel 1) dan uji organoleptik (tabel 2 dan 3), menginformasikan bahwa bentuk inovasi jajanan sehat berbahan ikan laut lebih mendominasi penilaian kesukaan panelis. Jenis ikan yang digunakan dapat diterima secara keseluruhan. Berdasarkan hal tersebut maka daging ikan yang mengandung asam lemak relatif tinggi seperti tuna, tengiri, tongkol, dan kembung merupakan alternatif pilihan untuk dikembangkan dalam bentuk jajanan yang disukai anak-anak (tabel 2 dan 3). Adapun jajanan anak berbahan dasar ikan laut hasil rekayasa yang dapat dikembangkan sebagai pangan fungsional adalah sebagai berikut:

\section{Nugget ikan}

Merupakan jajanan modern yang paling disukai anak-anak. Nugget ikan disimpan beku dalam kondisi digoreng setengah matang, hal ini dimaksudkan untuk menghindari pemasakan yang berlebih (gosong) pada saat digoreng ulang sebelum disajikan (Pornomowati et al., 2008).

\section{Chury burger}

Jajanan modern bentuk burger dengan isi daging tuna lumat yang ditumis dengan bawang bombay dan bawang putih. Kombinasi lembaran keju, saos tomat dan mayonais memberikan rasa gurih yang memberikan kesan modern. Rasa, tekstur, bentuk dan aroma jajanan ini sangat disukai anak-anak (Yahyono, 2009)

\section{Bitter balen}

Jajanan ini merupakan hasil inovasi jajanan tradisional Kroket yang di produksi khusus untuk simpan beku. Ukuran dan bentuk kecil-kecil menjadikan jajanan ini sangat disukai anak-anak. (Pornomowati et al., 2008)

\section{Fish cake}

Jajanan modern ini terdiri dari irisan keju yang diselimuti gilingan daging ikan berbumbu dan pada bagian luar ditaburi tepung roti (Pornomowati et al., 2008). Pada penelitian ini jajanan fish cake dirancang dalam produk olahan beku. 


\section{Fish burger}

Pangan fungsional bentuk burger dalam penelitian ini khusus direkayasa simpan beku. Proses penghangatan atau pelunakan burger sebelum disajikan dapat dilakukan dengan oven atau microwave atau dikukus (Lumbong et al., 2017; Yahyono, 2009)

\section{Breaded fish}

Jajanan ini terbuat dari daging ikan filet berbumbu, pada lapisan luar diberi taburan tepung roti basah. Penggunaan tepung roti dapat dimodifikasi dengan campuran tepung beras, tepung jagung dan tepung gandum, sedangkan metode pemasakan dapat disajikan digoreng atau dipanggang (Bechtel et al., 2018). Breaded fish merupakan salah satu jenis makanan siap saji yang banyak disukai konsumen karena rasa, penampilan dan kepraktisannya. Pada penelitian ini jajanan breaded fish dirancang dalam produk olahan beku.

\section{Fish stick}

Rasa dan tekstur jajanan ini hampir menyerupai fish cake. Adapun kekhasan jajanan ini adalah berasa asin dan sedikit manis dan tekstur yang agak kasar. Fish stick terbuat dari daging ikan yang digiling kasar yang dicampur dengan tepung roti tawar basah (Pornomowati et $a l .$, 2008). Pada penelitian ini jajanan fish stick dirancang dalam produk olahan beku beku.

\section{Pastel beku}

Hasil rekayasa jajanan tradisional Pastel dalam penelitian ini dibuat secara praktis dengan menggunakan cetakan. Isi pastel terdiri dari daging ikan giling yang dicampur dengan adonan pati umbi (Tyas, 2017). Pada penelitian ini jajanan Pastel dirancang dalam produk olahan beku

\section{Siomay ikan}

Rekayasa jajanan siomay ikan pada penelitian ini, merupakan produk hasil inovasi bakso ikan yang dibungkus dengan kulit lumpia. Jajanan siomay ikan dikonsumsi dalam bentuk steam atau frying (Nessianti \& Dewi, 2015). Pada penelitian ini jajanan siomay ikan dirancang dalam produk olahan beku beku.

\section{Shi kebab}

Merupakan jajanan khas Timur Tengah yang mempunyai rasa dan aroma kuat rempah-rempah. Penyajian seperti sate dan mudah untuk menyantapnya membuat jajanan ini disukai anak-anak Berdasarkan hasil penelitian dengan bahan utama kebab (daging sapi, ayam dan ikan) adalah bahan yang sangat mudah rusak dan rentan terhadap kontaminasi mikroba. Berdasarkan hal tersebut maka inovasi shi kebab pada penelitian ini direkayasa simpan beku (Choiriyah et al., 2016).

\section{Empek-empek}

Jajanan tradisional khas kota Palembang, hasil rekayasa jajanan anak ini dalam penyajiannya dibuat dalam bentuk potongan bulat-memanjang yang ditusuk dengan tusukan sate (Tyas, 2017). 


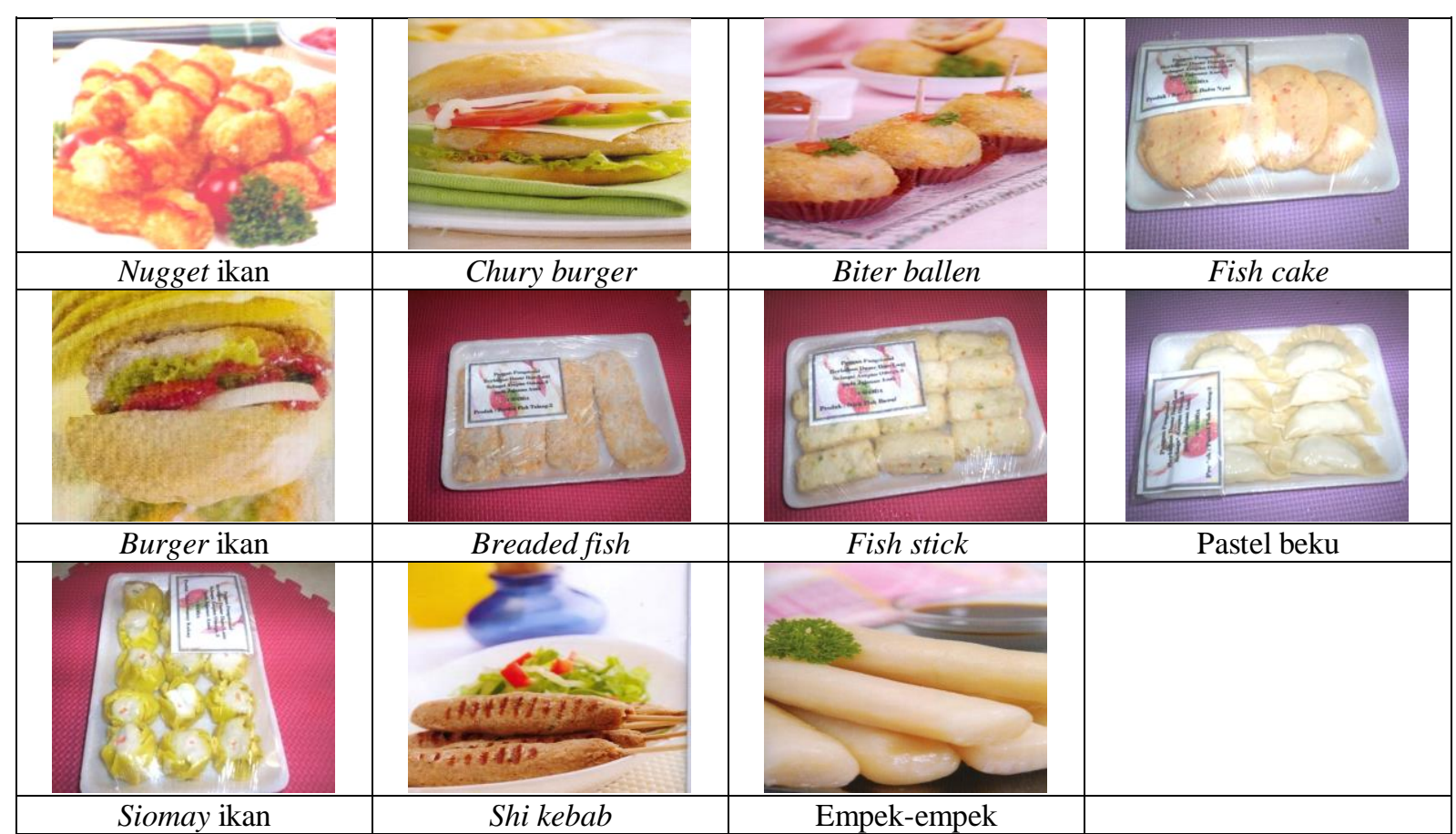

Gambar 1. Jajanan sehat yang direkomendasikan untuk dikembangkan

\section{KESIMPULAN}

Hasil penelitian tahap 1, menginformasikan bahwa ikan laut hasil tangkapan yang ditemukan di lokasi kajian sebanyak 13 jenis, yaitu ikan talang-talang, tongkol , tengiri, banyar, selar, bawal, ekor kuning, banyar, kakap putih, kakap merah , babu nyai, alu-alu dan belanak.

Hasil penelitian tahap 2, rekayasa jajanan sehat berbahan dasar ikan laut dilakukan terhadap 14 produk dan telah dilakukan tes organoleptik (uji kesukaan). Hasil uji kesukaan sebagai berikut: jajanan bitter ballen dan churry burger sangat disukai, sedangkan breaded fish, pastel, scallop, Nugget, siomay, fish cake, burger, stick fish, dan shi kebab menyukai hingga sangat menyukai, sedangkan bakso ikan biasa hingga menyukai, dan Ekado relatif tidak disukai. Produk jajanan tradisional berbahan dasar ikan dilakukan terhadap 11 produk dengan hasil uji kesukaan bahwa empek-empek, Kroket, Lumpia basah dan goreng, Lemper masih disukai hingga sangat disukai, sedangkan condro, pastel, aremarem, onde-onde, otak-otak, dan bakwan berkisar tidak menyukai hingga biasa.

\section{UCAPAN TERIMA KASIH}

Ucapan terima kasih diperuntukkan kepada Balitbang Propinsi Jawa Timur, Fakultas Perikan dan Ilmu Kelautan Universitas Brawijaya dan laboratorium Pengujian Mutu dan Keamanan Pangan (PMKP) Universitas Brawijaya.

\section{DAFTAR PUSTAKA}

Bechtel, P. J., Bland, J. M., Woods, K., Lea, J. M., Brashear, S. S., Boue, S. M., Daigle, K. W., \& Bett-Garber, K. L. (2018). Effect of par frying on composition and texture of breaded and battered catfish. Foods, 7(4), 1-11. https://doi.org/10.3390/foods7040046

Choiriyah, S., Hestiningsih, R., \& Yuliawati, S. (2016). Gambaran jumlah kuman total pada sampel daging kebab stand di kota Semarang. Jurnal Kesehatan Masyarakat Universitas Diponegoro, 4(4), 460-464.

Dahuri, R. (2002). Membangun kembali perekonomian Indonesia melalui sektor perikanan dan kelautan. LISPI.

Diana, F. M. (2013). Omega 3 dan kecerdasan anak. Jurnal Kesehatan Masyarakat, $\quad 7(2), \quad 82-88$. 
https://doi.org/10.24893/jkma.v7i2.113

Duthie, I. F., \& Barlow, S. M. (1992). Dietary lipid exemplified by fish oils and their n-3 fatty acid. Food Science Technology, 6, 20-35.

Dyna, F., Putri, V. D., \& Indrawati, D. (2018). Hubungan perilaku komsumsi jajanan pada pedagang kaki lima dengan kejadian diare. Jurnal Endurance, 3(3), 524-530. http://doi.org/10.22216/jen.v3i3.3097

Herawati, E. Y. (2019). Identifikasi jenisjenis phytoplankton pada tambak bandeng dengan kualitas omega-3 tinggi. Journal of Fisheries and Marine Research, 3(2), 258-262.

Hosomi, R., Yoshida, M., \& Fukunaga, K. (2012). Seafood consumption and components for health. Global journal of health science, 4(3), 72-86. https://doi.org/10.5539/gjhs.v4n3p72

Iklima, N. (2017). Gambaran pemilihan makanan jajanan pada anak usia sekolah dasar. Jurnal Keperawatan BSI, $\quad 5(1), \quad 8-17$. https://doi.org/10.31311/.v5i1.1774

Lumbong, R., Tinangon, R. M., Rotinsulu, M. D., \& Kalele, J. A. D. (2017). Sifat organoleptik burger ayam dengan metode memasak yang berbeda. Zootec, 37(2), 252-258. https://doi.org/10.35792/zot.37.2.2017. 16000

Nessianti, A., \& Dewi, R. (2015). Pengaruh penambahan puree labu siam (sechium edute) terhadap sifat organoleptik siomay ikan tengiri (scomberomorus commersonil). Jurnal Boga, 4(3), 7984.
Nurbiyati, T. (2014). Pentingnya memilih jajanan sehat demi kesehatan anak. Asian Journal of Innovation and Entrepreneurship, 3(3), 192-196.

Purnomowati, I., Diana, H., \& Cahyo, S. (2008). Aneka kudapan ikan. Kanisius.

Chadwick, R., Henson, S., Moseley, B., Koenen, G., Liakopoulos, M., Midden, C., \& Schröder, D. (2003). Functional foods (Eds. 20). Springer Science \& Business Media.

Tyas, A. S. P. (2017). Identifikasi kuliner lokal Indonesia dalam pembelajaran bahasa Inggris. Jurnal Pariwisata Terapan, 1(1), $38-51$. https://doi.org/10.22146/jpt.24970

Syam, A., Indriasari, R., \& Ibnu, I. (2018). Gambaran pengetahuan dan sikap siswa terhadap makanan jajanan sebelum dan setelah pemberian edukasi kartu kwartet pada anak usia sekolah dasar di kota Makassar. Jurnal Tepat: Applied Technology Journal for Community Engagement and Services, 1(2), 127-136. https://doi.org/10.25042/vol1iss2pp127 $-136$

Usydus, Z., \& Szlinder-Richert, J. (2012). Functional properties of fish and fish products: A review. International Journal of Food Properties, 15(4), 823-846. https://doi.org/10.1080/10942912.2010 .503356

Yahyono, S. S. (2009). Burger favorit dan sehat. Dian Rakyat. 